\title{
Development of a strategy for improving organizational and production structures based on methods for non-convex programming
}

\author{
Igor Novakivskyi ${ }^{1}$, Vasyl Kozyk ${ }^{1}$, Oleksandra Mrykhina ${ }^{1 *}$ and Orest Koleshchuk ${ }^{1}$ \\ ${ }^{1}$ Lviv Polytechnic National University, Institute of Economics and Management, Bandery Str., 12, \\ 79013 Lviv, Ukraine
}

\begin{abstract}
The scientific paper discloses problems of functioning of financial industrial groups, particularly their flexible organizational and production structures. The authors highlight that maintaining sustainability of development of financial industrial groups is oriented towards preserving integrity of their organizational and production structures and keeping a set of parameters within given limits, taking into account internal disturbances and external impacts. Generally, sustainable development of organizational and production structures contemplates concerted actions directed towards accomplishing the following two goals: maximizing indicators displaying results of activities of an organizational and production structure through determining optimal amounts of investments by different directions of activity of its modules, as well as minimizing a probable deviation from planned results by directions of activity. The authors have built a two criteria mathematical model for managing development of prospective directions of activities of organizational and production structures, which takes into account their riskiness and is based on retrospective data. To search the optimal value of a functional, the authors have developed a four-step algorithm for solving the indicated problem. To solve the indicated problem of constrained optimization, the authors have applied the method of steepest descent.
\end{abstract}

\section{Introduction. The growing importance of organizational and production structures in the contemporary economy}

Contemporary corporations implement elements of virtualization of their organizational and production structures to dynamically react to changes of a market under the scientific and technological progress. This fact is confirmed by a dramatic increase of a share of products having the five-year life cycle. Therefore, a standard of manufacturing such products should contemplate rapid dismantling and recycling both a product and production capacities. P. Drucker [2] asserts that corporations of the $21^{\text {st }}$ century will be an organized set of production modules, which encompasses a production process stage or several

* Corresponding author: oleksandramrykhina@gmail.com 
similar operations. Although general management of a corporation continues to perform its functions, an environment of an organizational and production structure will form own horizontal system of management for the interaction between its modules, as well as numerous stakeholders from an external environment. The problems of the strategy for improving organizational and production structures are described in the works [1-10].

Under the above-mentioned changes, the large-scale formation of modern viable organizational and production structures and developing effective mechanisms for managing them oriented towards the network market economy are important goals for development of financial industrial groups. In this case, a paramount aim consists in improving methods of management oriented towards the situational approach. This will enable to maintain sustainable development of organizational and production structures and to reduce negative risks of an external environment.

\section{Methodical approaches to developing the strategy for improving organizational and production structures}

Under traditional conditions, management of improving organizational and production structures is aimed at supporting sustainable development and protecting departments of an enterprise against the influence of external or internal threats. Maintaining sustainability of development of the potential of financial industrial groups is directed towards preserving integrity of their organizational and production structures and keeping a set of parameters within given limits, taking into account internal disturbances and external impacts, which dynamically grow under the increase of the informatization level of an external environment. Figure 1 shows a scheme of this process.

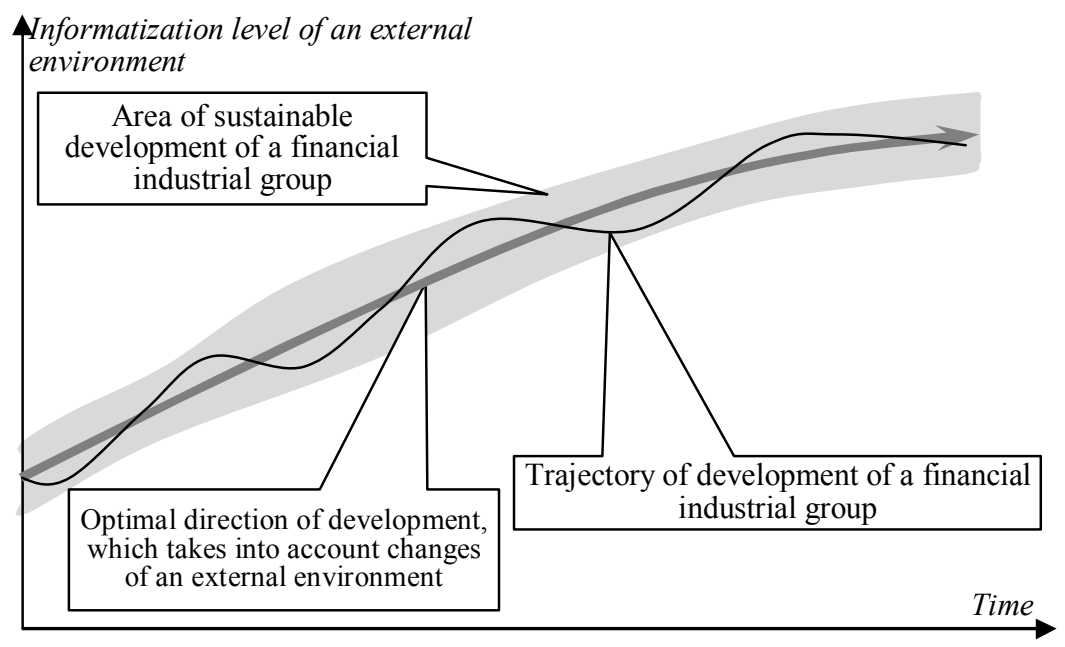

Fig. 1. Scheme of development of financial industrial groups over time.

Borders of the area of sustainable development change during evolvement of financial industrial groups while any change of their organizational and production structures influences the placement and size of the area of sustainability, which may be limited by the threshold value of selected indicators. Threshold values are marginal values the structures should not move beyond to reproduce internal elements and to avoid forming negative destructive tendencies. The approximation to their maximum permissible value indicates the increment of threats to socio-economic stability of organizational and production structures, i.e. a real threat to economic security of financial industrial groups. To ensure the high level of economic security, a structure should not exceed marginal costs. 
Obviously, maintaining a higher level of economic security of an enterprise increases economic pressure on the potential of an organizational and production structure. This pressure is able to maintain a set of stabilization measures.

Economic security of functioning of financial industrial groups considerably depends on an accepted conception of risk management. Effective management should ensure sustainable development of an enterprise because its ability to accomplish determined goals may not only undermine competitive positions of financial industrial groups in a market but also lead to bankruptcy.

\section{Mathematical model for management of improving organizational and production structures}

Sustainable development of an enterprise implies achieving the following two objectives: maximizing indicators displaying results of activities of an organizational and production structure through determining optimal amounts of investments by different directions of activity of its modules; minimizing a probable deviation from planned results by directions of activity. The first objective can be achieved through maximizing the profitability index. In this case, it is expedient to use a quadratic form for determining dependence of the profitability index of an enterprise from amounts of investments by directions of activity of an organizational and production structure. This may be presented in the form of the following functional:

$$
F=\left(\begin{array}{llll}
1 & q_{1} & \cdots & q_{n}
\end{array}\right) \times\left\|\begin{array}{cccc}
\alpha_{00} & \alpha_{01} & \cdots & \alpha_{0 n} \\
\alpha_{10} & \alpha_{11} & \cdots & \alpha_{1 n} \\
\cdots & \cdots & \cdots & \cdots \\
\alpha_{n 0} & \alpha_{n 1} & \cdots & \alpha_{n n}
\end{array}\right\| \times\left(\begin{array}{c}
1 \\
q_{1} \\
\vdots \\
q_{n}
\end{array}\right) \rightarrow \max ,
$$

where $F$ - criterion function for profitability of enterprise's investments, arb. units; $\alpha_{i j}-$ indicators presented in the quadratic form, which satisfy a condition $\alpha_{i j}=\alpha_{i j}$ and are determined owing to the correlation and regression analysis of statistical data describing activity of an enterprise, $1 /$ hryvnia $^{2}$; vector $\left(1 ; q_{1} ; q_{2} ; \ldots q_{n}\right)$ consists of an auxiliary unit of measurement and unknown amounts of investments $q_{1} ; q_{2} ; \ldots q_{n}$, hryvnias, $n$ - number of directions of activity of the enterprise, units.

The criterion function (1) determines dependence of the profitability index of an enterprise from amounts of investments by directions of activity, i.e. the problem amounts to determining unknowns $\left\{q_{i}\right\}_{i=1}^{K}$. Affordable amounts of investments are typical additional conditions for this problem.

To ensure maximum sustainability by types of enterprise's activity, it is expedient to minimize a probable discrepancy of profitability indices by directions of enterprise's activity. In this case, it is necessary to use properties of the analysis of covariance applied in planning and statistical processing of experimental results as a method for reducing an experimental error, which cannot be directly measured. In general, the problem regarding minimizing uncertainty, which is stipulated by risks, in the integrated form by all declared directions of enterprise's activity may be amounted to ascertaining a minimum of a quadratic functional:

$$
V=\frac{1}{\|q\|^{2}}\left(\begin{array}{lll}
q_{1} & \cdots & q_{n}
\end{array}\right) \times\left\|\begin{array}{cccc}
v_{11} & v_{12} & \cdots & v_{1 n} \\
v_{21} & v_{22} & \cdots & v_{2 n} \\
\cdots & \cdots & \cdots & \cdots \\
v_{n 1} & v_{n 2} & \cdots & v_{n n}
\end{array}\right\| \times\left(\begin{array}{c}
q_{1} \\
q_{2} \\
\cdots \\
q_{n}
\end{array}\right) \rightarrow \min ,
$$


where $V$ is functional, which determines the value of dispersion of profitability indices by directions of activity, $v_{i j}$ is modified covariance coefficient calculated according to the formula:

$$
\begin{gathered}
v_{i j}=\frac{\operatorname{cov}_{i j}}{\beta_{i} \times \beta_{j}}, \quad \beta_{k}=\left\{\begin{array}{cc}
\beta_{k}, & \beta_{k} \geq \beta_{k}^{\text {(crit) }} \\
\beta_{k}^{\text {(crit) }}, & \beta_{k}<\beta_{k}^{\text {(crit) }},
\end{array}\right. \\
\operatorname{cov}_{i j}=\frac{\sum_{k=1}^{K}\left(\left(\bar{\beta}_{i}-\beta_{i, k}\right) \times\left(\bar{\beta}_{j}-\beta_{j, k}\right)\right)}{k-1}, \\
\|q\|^{2}=\left(\sum_{i=1}^{n} q_{i}^{2}\right) / n,
\end{gathered}
$$

where $\beta_{k}{ }^{(c r i t)}$ is value of profitability of investments given beforehand (if the value of the profitability index is less than the specified one, it is insignificant for an enterprise), hryvnias,

$$
\bar{\beta}_{i}=1 / n \sum_{k=1}^{n} \beta_{i k}
$$

where $\bar{\beta}_{i}$ is average value of profitability of investments for the $i$ direction of activity, hryvnias; $\left\{\beta_{i k}\right\}_{k=1}^{K}$ is data of statistical examination concerning the profitability ratio for the $i$ direction of activity, arb. units; $K$ is number of points of statistical observation, units.

To determine the optimal structure of investing in directions of activity of an organizational and production structure, the authors have proposed to apply the following functional:

$$
W=F / V \rightarrow \max
$$

where $W$ - functional, which logically combines requirements of maximizing the functional $F$ and minimizing the $V$. Formulas for calculation of the mentioned values are presented in the formulas (1) and (2). The functional $W$, which is presented in (4), reflects consolidated dependence of maximizing the generalized profitability index and minimizing the average dispersion of partial indices by directions of activity of an organizational and production structure. Thus, the two criteria problem has been amounted to a single-criterion problem. To solve the latter, the authors recommend using the method of nonlinear convex programming in a value domain. To ascertain optimal values of the functional $F$, which is disclosed in (4), the authors recommend using the following algorithm:

1. Collecting and processing of statistical data on a researched organizational and production structure regarding funds invested in certain directions of activity of an organizational and production structure and earned profits correspondingly.

2. Building the quadratic functional $F$, which is presented in (1), for calculation of the profitability index of an organizational and production structure according to amounts of investments in directions of its activity. To determine unknown coefficients of the required multi-factor equation, economists should apply classic methods of the correlation and regression analysis for collecting statistical data.

3. Building the quadratic functional $V$, which is presented in (2), for assessing the dispersion of profitability indices by directions of activity of an organizational and production structure. To achieve this goal, economists should calculate a covariance matrix according to the formulas (3) based on the collected statistical data.

4. Determining a maximum of the functional $W$, which is disclosed in (4), through applying an iterative optimization algorithm, namely the method of steepest descent. 


\section{Example of the calculation for the Energoresurs-Invest Corporation}

To calculate indicators, the authors have used statistical data for 2002-2016 by two directions of activity of the corporation adjusted for inflation according to the last year of observation (Table 1).

Table 1. Results of activity of the Energoresurs-Invest Corporation

\begin{tabular}{|c|c|c|c|c|}
\hline Years & $\begin{array}{c}\text { Amount of } \\
\text { investments for } \\
\text { the first } \\
\text { direction, } \\
\text { thousand } \\
\text { hryvnias }\end{array}$ & $\begin{array}{c}\text { Amount of } \\
\text { investments for } \\
\text { the second } \\
\text { direction, } \\
\text { thousand } \\
\text { hryvnias }\end{array}$ & $\begin{array}{c}\text { Gross profit for } \\
\text { the first } \\
\text { direction, } \\
\text { thousand } \\
\text { hryvnias }\end{array}$ & $\begin{array}{c}\text { Gross profit for } \\
\text { the second } \\
\text { direction, } \\
\text { thousand } \\
\text { hryvnias }\end{array}$ \\
\hline 2002 & 395.9 & 678.7 & 14.9 & 266.4 \\
\hline 2003 & 508.2 & 564.7 & 193.2 & 27.1 \\
\hline 2004 & 481.1 & 841.9 & 106.5 & 536.7 \\
\hline 2005 & 963.8 & 783.1 & 766.8 & 413 \\
\hline 2006 & 813.8 & 871.9 & 652 & 630.2 \\
\hline 2007 & 987.4 & 603.4 & 681.8 & 140.4 \\
\hline 2008 & 360 & 1020 & -61.5 & 835 \\
\hline 2009 & 720.9 & 961.2 & 509.9 & 752.7 \\
\hline 2010 & 601.1 & 1322.4 & 309 & 824.2 \\
\hline 2011 & 864.9 & 1383.9 & 701.3 & 513.6 \\
\hline 2012 & 1012.3 & 1250.5 & 764.7 & 890.5 \\
\hline 2013 & 1045.3 & 1045.3 & 627.9 & 852 \\
\hline 2014 & 1322 & 1081.7 & 240.7 & 897 \\
\hline 2015 & 1170.4 & 1114.7 & 405.5 & 865 \\
\hline 2016 & 1204.9 & 1385.6 & 585.6 & 706.2 \\
\hline
\end{tabular}

In case of considering only two directions of activity of the Energoresurs-Invest Corporation, the functional (4) may be presented by the following formula:

$$
W=\frac{\alpha_{00}+2 \alpha_{01} q_{1}+2 \alpha_{02} q_{2}+\alpha_{11} q_{1}^{2}+2 \alpha_{12} q_{1} q_{2}+\alpha_{22} q_{2}^{2}}{\left(v_{11} q_{1}^{2}+2 v_{12} q_{1} q_{2}+v_{22} q_{2}^{2}\right) /\left(q_{1}^{2}+q_{2}^{2}\right)} \rightarrow \max ,
$$

where $W$ is calculated functional according to the statistical data shown in Table $1, q_{1}, q_{2}$ are amounts of investments by two directions of activity of the corporation.

In consistency with paragraphs 1-3 of the suggested algorithm, the authors have computed coefficients of the functional $W$ form the formula (5) according to the data shown in Table 1 and, therefore, obtained:

$$
W=\frac{-1,979501+0,025607 q_{1}+0,036732 q_{2}-0,000138 q_{1}^{2}-0,000045 q_{1} q_{2}-0,000174 q_{2}^{2}}{\left(q_{1}^{2}-0,1838_{12} q_{1} q_{2}+q_{2}^{2}\right) /\left(q_{1}^{2}+q_{2}^{2}\right)} \rightarrow \max .
$$

Additional conditions of the problem display requirements to amounts of investments: 


$$
125 \leq q_{1} \leq 500 ; \quad 250 \leq q_{2} \leq 625 ; \quad q_{1}+q_{2} \leq 1000 .
$$

Applying the method of steepest descent for solving the indicated problem of constrained optimization has enabled to obtain the following results: the maximum value of the functional $W=1.82$, the profitability index of the corporation equals 0.77 , and recommended amount of investments for the first direction accounts for 427.9 thousand hryvnias and for the second direction accounts for 522.6 thousand hryvnias.

\section{Conclusions}

It is worth mentioning that the outlined approach may be exploited for solving a number of similar problems, e.g. regarding optimization of enterprise's profit. The authors have applied this approach for optimization of choosing the main directions at the EnergoresursInvest Corporation. As a result, an amount of revenue of the corporation has increased, on average, by $3.2 \%$.

Results of applying the suggested criterion of efficiency (4) for various goals related to choosing optimal solutions under conditions of uncertainty show that the proposed approach is effective.

In general, maintaining sustainability of development of financial industrial groups should primarily contemplate modernization of their organizational and production structure, exploiting new opportunities of the scientific and technological progress in economic activity, as well as in globalization of business interrelations.

\section{References}

1. I. Adizes, Upravlenie zhiznennyim tsiklom korporatsii [Life Cycle Management Corporation], (Ed. by A. G. Seferyan), SPb.: Piter (2007). [In Russian]

2. P. F. Druker, Ryinok: kak vyiyti v lideryi. Praktika $i$ printsipyi [How to get to the leaders. Practice and principles], Moscow, Ekonomika (1992). [In Russian]

3. N. I. Chukhray, O. B. Mrykhina, Theoretical and methodological basis for technology transfer from universities to the business environment, Problems and Perspectives in Management, 16(1) (2018).

4. O. I. Karyi, Lohistychna infrastruktura v Ukraini: tsyfry i realnist [Logistics Infrastructure in Ukraine: Figures and Reality], Lohistyka, 762 (2013). [In Ukrainian]

5. O. Koleshchuk, V. Lesinskyi, O. Yemelyanov, O. Zarytska, A. Symak, Substantiation of projects that account for risk in the resource-saving technological changes at enterprises, Eastern-European Journal of Enterprise Technologies, 6(1-96) (2018).

6. V. Kozyk, O. Mrykhina, T. Mirkunova, Conceptual model for economic evaluation of innovative technologies, Economics, Entrepreneurship, Management, 4(2) (2017).

7. O. V. Moroz, N. P. Karachyna, T. M. Khalimon, Korporatyvne upravlinnia na pidpryiemstvakh Ukrainy: postpryvatyzatsiinyi etap evoliutsii [Corporate Governance at Ukrainian Enterprises: Post-Privatization Stage of Evolution], Vinnytsia: UNIVERSUM (2008). [In Ukrainian]

8. J. M. Petrovich, I. I. Novakivskyi, Modern concept of a model design of an organizational system of enterprise management, Econtechmod, 1 (4), Lublin - Lviv Cracow (2012).

9. A. Toffler, The adaptive corporation, Aldershot: Gower (2005).

10. V. Trynchuk, P. Horyslavets, M. Plonka, Experience marketing and its tools in promoting the insurance services, Innovative Marketing, 14 (2018). 